\title{
A RECEPÇÃO DE PAPÉIS AVULSOS E A CRISTALIZAÇÃO DE LUGARES- COMUNS DA CRÍTICA MACHADIANA: PROPOSTA ANALITICA E EDITORIAL
}

\section{THIAGO MIO SALLA}

Universidade de São Paulo

São Paulo, São Paulo, Brasil

\section{LUIZA HELENA DAMIANI AGUILAR}

Universidade de São Paulo

São Paulo, São Paulo, Brasil

Resumo: Este artigo tem como objetivo recuperar e analisar textos críticos publicados quando do lançamento da primeira edição de Papéis avulsos, considerado o primeiro livro de contos da chamada "segunda maneira" de Machado de Assis. Procura-se examinar como a recepção ao livro em questão, depois do desconcerto causado na crítica com a edição das Memórias póstumas de Brás Cubas, corrobora a proeminente posição que já vinha sendo ocupada pelo autor, bem como desdobra e cristaliza alguns lugares-comuns que, posteriormente, irão se consolidar ao longo da tradição de leitura de sua obra. O artigo reúne também, em anexo, uma proposta de edição da fortuna crítica de Papéis avulsos publicada em periódicos no calor da hora, sobretudo, ao final de 1882.

Palavras-chave: Machado de Assis; Papéis avulsos; Memórias póstumas de Brás Cubas; Contos; "Segunda maneira de Machado".

\section{THE RECEPTION OF PAPÉIS AVULSOS AND THE CRYSTALLIZATION OF CRITICAL COMMON PLACES IN THE WORK OF MACHADO DE ASSIS: AN ANALYTICAL AND EDITORIAL PROPOSAL}

\begin{abstract}
The objective of this article is to analyse the reviews published in newspapers in response to the publication of the first edition of Papéis avulsos, considered to be the first collection of short-stories in Machado de Assis's so-called "second phase." The study aims to examine how the book's reception in the aftermath
\end{abstract}


of the clamour caused by the publication of Memórias póstumas de Brás Cubas corroborates the confirmation of the prominent place the author occupied, and also crystallizes some commonplaces that the critics would later be consolidate through the tradition of reading Machado's work. The annex of this article also offers a proposal for editing the wealth of spur-of-the-moment criticism written about Papéis avulsos in newspapers, specifically in late 1882.

Keywords: Machado de Assis; Papéis avulsos; Memórias póstumas de Brás Cubas; Short Stories; "Machado's Second phase".

pesar de hoje ser considerado como "o romance mais abusado
produzido no Brasil oitocentista" (GUIMARÃES, 2004a, p. 192) e o
"primeiro romance brasileiro de qualidade internacional" (SCHWARZ, 2010, p. 242), Memórias póstumas de Brás Cubas teve fria recepção na imprensa logo depois de sua publicação em suporte livresco, no início de 1881. Pelo que se sabe, a obra foi alvo de apenas três notas curtas e de três comentários analíticos mais alentados saídos em diferentes publicações da corte. ${ }^{1}$ Entre as críticas de maior extensão, por sua vez, prevalecia a desorientação diante de um livro portador, por um lado, de um colorido pouco definido ("estilo furta-cor") e desprovido, por outro, do enredo tradicional em que o leitor vulgar encontraria "pasto" para sua imaginação e curiosidade banais (DUARTE, 1881, p. 2). Não por acaso, no início de sua avaliação do volume, Capistrano de Abreu se questionava se estava, de fato, diante de um romance (ABREU, 1881, p. 2). Em carta a Machado, ele chegou até mesmo a afirmar que não tinha certeza se havia sido capaz de compreender a intenção latente da obra (ABREU apud MAGALHÃES JÚNIOR, 1981, p. 11). De modo análogo, mas no corpo de sua crônica estampada na Gazetinha, Urbano Duarte, por mais que rebaixe as Memórias póstumas, chega a externar sua dificuldade em "interpretar ou mesmo adivinhar a ideia mãe da obra, descobrir a bússola que dirige a pena do escritor" (DUARTE, 1881, p. 2). Tal acolhida pouco favorável, ${ }^{2}$ motivada, em princípio, pelos "embaraços que a novidade da obra criou para os seus primeiros leitores" (GUIMARÃES, 2004a, p. 192), teria sido desanimadora

\footnotetext{
${ }^{1}$ A primeira recepção de Memórias póstumas de Brás Cubas, publicada em jornal, abarcaria os seguintes textos: POMPEIA, 1880, p. 2; RECEBEMOS, 1881, p. 1; JÚNIO, 1880, p. 6; ABREU, 1881, p. 2; DUARTE, 1881, p. 2; ABDIEL, 1881, p. 40.

${ }^{2}$ As exceções seriam a curta nota assinada por Raul Pompeia e o texto de Abdiel.
} 
para Machado, que, apesar do percalço, foi aconselhado pelo cunhado a perseverar na escrita (GUIMARÃES, 2004a, p. 193).

Tal relato a respeito das primeiras avaliações das Memórias póstumas de Brás Cubas já é bem conhecido graças aos trabalhos pioneiros de Ubiratan Machado (2003) e, sobretudo, de Hélio de Seixas Guimarães (2004a; 2017). Contudo, quais seriam os desdobramentos na recepção da obra de Machado de Assis logo após o desconcerto causado por esse livro singular, escrito com a pena da galhofa e a tinta da melancolia? Sabe-se que a crítica machadiana ganharia corpo, efetivamente, apenas cerca de dez anos depois, quando, enfim, o próximo romance do autor, Quincas Borba (1891), seria lançado (GUIMARÃES, 2008, p. 32). Apesar de ainda se fazer presente o descompasso entre as resenhas e a obra, esta alcançaria calorosa repercussão e reconhecimento quase geral (GUIMARÃES, 2008, p. 32-33). Para além desse salto de uma década, o que a primeira recepção do livro de contos Papéis avulsos, publicado apenas um ano depois da edição em livro de Memórias póstumas, já teria a nos dizer a respeito da acolhida da chamada "segunda maneira" do escritor?

A resposta a essa pergunta pressupõe, todavia, superar um questionamento de fundo: se, conforme aponta John Gledson, fora dada importância menor ao estudo dos contos de Machado em comparação com a literatura crítica que trata dos romances (GLEDSON, 2006b, p. 35), o que dizer de estudos a respeito da história da leitura de tal produção? Partindo dessa indagação, pretende-se recuperar e investigar, aqui, justamente, de que modo a fortuna crítica construída logo após o lançamento de Papéis avulsos desdobra e cristaliza alguns lugares-comuns da crítica machadiana, os quais, posteriormente, irão se consolidar ao longo da tradição de leitura da obra do autor.

\section{Papéis avulsos e a consagração pós-desconcerto}

Publicada em 1882 pela Lombaerts \& $\mathrm{Cia},{ }^{3}$ a coletânea Papéis avulsos é considerada pela crítica contemporânea à edição do livro como um marco que, ao mesmo tempo, consolida e inaugura a chamada "segunda maneira" de Machado de Assis: consolida-a, ao confirmar a orientação literária fundante

\footnotetext{
${ }^{3} \mathrm{Na}$ folha de rosto do livro, aparece o nome da Lombaerts \& Cia. De acordo com Laurence Hallewell (2005, p. 229), em seu estudo sobre o livro no Brasil, a Lombaerts realizou muitos trabalhos de impressão por encomenda e, dentre eles, o estudioso inglês elenca duas produções de Machado que foram solicitadas a tal casa editorial pela Garnier: Histórias sem data (1884) e Quincas Borba (1891).
} 
nas Memórias póstumas, marcada pela presença daquilo que, na época, foi visto, entre outros aspectos, como uma "filosofia" ou "humorismo triste"; e inaugura-a na contística do autor, por mais que três versões preliminares de contos presentes no volume tenham sido estampadas de modo disperso em periódicos antes mesmo do início da publicação da história narrada por Brás Cubas. $^{4}$

A coletânea conta com doze textos (com destaque para "O alienista", "Teoria do medalhão" e "O espelho") nos quais se fazem presentes muitos elementos que fugiam aos preceitos mais comuns das escolas literárias vigentes na época. Em tais narrativas multifacetadas, o autor solta "as rédeas à ironia", aproximando-se dos padrões do humour inglês do século XVIII. A eleição de tal perspectiva artística, "inventad[a] por algum grego da decadência, contraíd[a] por Luciano, transmitid[a] a Swift e Voltaire" (ASSIS, 1882, p. 103-104) reforçou a percepção crítica, cuja construção teve início naquele momento, de que Machado seria um deslocado, um inglês perdido em terras brasileiras. Em um cenário no qual tanto realismo quanto naturalismo procuravam produzir o efeito de veridicção, ancorando-se em discursos afeitos à representação de práticas e noções comuns à contemporaneidade de então, Machado adota caminhos distintos. Dentre as narrativas presentes na obra, "Na arca" e "O segredo do bonzo", por exemplo, são pastiches respectivamente da Bíblia e das Peregrinações de Fernão Mendes Pinto. "A sereníssima República" e "Uma visita de Alcebíades" são exemplos de textos que trabalham muito com a dimensão da fantasia. Seja no que diz respeito ao estilo adotado ou aos assuntos abordados, Machado, em certa medida, parece colocar em prática aquilo que enuncia em textos críticos dos anos 1870, com destaque para "Instinto de nacionalidade" (1873) e a crítica ao romance $O$ primo Basílio, de Eça de Queirós (1878), procurando tratar do Brasil às avessas, "através de excursões no tempo e no espaço" (GLEDSON, 2011, p. 10).

Ao todo, sobretudo no transcorrer dos últimos meses de 1882, foram encontrados na imprensa da corte quatro pequenas notas e oito comentários críticos mais extensos a respeito dos Papéis avulsos. ${ }^{5} \mathrm{Se}$, em termos gerais, o

\footnotetext{
${ }^{4}$ Trata-se dos contos "A chinela turca", "Uma visita de Alcebíades" e "Na arca", cujas primeiras versões, muitas delas consideravelmente diferentes daquelas recolhidas em Papéis avulsos, foram publicadas respectivamente, em A Epocha (14 nov. 1875), Jornal das Famílias (1º jan. 1876) e O Cruzeiro (14 maio 1878).

${ }^{5}$ ESTE ANO VAMOS, 1882, p. 1; PAPÉIS AVULSOS, Gazeta de Notícias, 1882a, p. 2; PAPÉIS AVULSOS, Gazeta da Tarde, 1882b, p. 1; PAPÉIS AVULSOS, Gazeta de Notícias, 1882c, p. 1; ARARIPE JÚNIOR, 1882a, p. 1; O QUE DIZER, 1882, p. 1; LAET, 1882, p. 1; ROZA, 1882, p. 1; SOB O TÍTULO, 1882, p. 2; DAST, 1882, p. 2; PAPÉIS AVULSOS, 1882d, p. 2; BIBLIOGRAFIA, 1882, p. 242. Para mais
} 
número de textos praticamente dobra em relação à fortuna crítica relativa às Memórias póstumas de Brás Cubas, as avaliações mais demoradas sobre a coletânea de contos quase triplicam. Bem verdade que ainda se está distante dos números alcançados por $O$ mulato de Aluísio Azevedo, romance que fora assunto de mais de cem artigos durante o ano de 1881 (CALDWELL, 1970, p. 117-118). Mas as novas toadas da prosa de Machado começavam a ganhar maior ressonância nos periódicos cariocas.

Para além de tal fortuna crítica, Papéis avulsos alcançara notoriedade já durante a década de 1880. O periódico A Semana, baluarte dos jovens escritores da época, dirigido por Valentim Magalhães, fez, em 1887, um "plebiscito literário" por meio do qual solicitava a seus leitores que participassem de enquete com vistas a eleger o "melhor romance", o "melhor livro de contos ou novelas", o "melhor drama" e a "melhor comédia". Ao encerramento de tal votação, que durou sete números e teve o resultado final publicado em 13 de agosto, Papéis avulsos foi considerado o vencedor como livro de contos, com 96 votos, 46 a mais que o segundo colocado, Histórias sem data, também de Machado de Assis. É curioso notar, ainda, que Memórias póstumas de Brás Cubas conquista a segunda colocação como melhor romance, perdendo por onze votos para $O$ guarani, de José de Alencar, que, juntamente com Bernardo Guimarães, é o único autor com mais de um título entre os concorrentes na categoria romance.

Enquanto retrato da vida literária tirado ao final do século XIX, essa eleição informal permite dimensionar a importância de Machado naquele momento, tanto para a literatura de modo geral como para o desenvolvimento do conto brasileiro. Há dois detalhes que demonstram esse fato com mais clareza: em primeiro lugar, embora a votação para "melhor livro de contos" apresentasse o menor índice de participação (178 votos no total), Papéis avulsos sagra-se vencedor em tal categoria com um número de escolhas similar aos vitoriosos nas demais; além disso, se somados os sufrágios dados a todos os títulos de Machado, ele é o autor de maior expressão do plebiscito, com um total de 233 votos, três a mais que José de Alencar, que possuía quatro obras entre as diferentes categorias (PLEBISCITO LITERÁRIO, 1887, p. 4).

Todavia, quando se analisa o conjunto de comentários e crônicas a respeito de Papéis avulsos antes referido, pode-se perceber que não é só esse certame promovido por A Semana que demonstra o prestígio de Machado no período. "Distinto literato", "nenhum dos nossos literatos tem hoje reputação

informações sobre tal conjunto de textos, conferir a proposta de edição da fortuna crítica de Papéis avulsos que, em anexo, acompanha o presente artigo. 
mais firmada do que aquele sr.", "estimável romancista", "um dos homens, que mais heroicamente hão concorrido para romper o indiferentismo que cerca as nossas letras", "escritor eminente de reputação legitimamente estabelecida", "escritor poderoso e sóbrio, perscrutador, original, moderno" são alguns dos inúmeros epítetos elogiosos atribuídos a ele pelos textos que saíram nos jornais na época da publicação de Papéis avulsos. ${ }^{6}$

\section{Matrizes da "segunda maneira"}

Quando se examina a história da crítica machadiana, José Veríssimo é visto como o primeiro a instituir a chave interpretativa que dividia a obra do escritor em "duas maneiras", tomando Memórias póstumas como o marco divisório entre uma e outra fase. Em 1898, quando da publicação da segunda edição de Iaiá Garcia, Veríssimo (1898, p. 249) pontua que tal romance pertenceria à primeira maneira de Machado, embora nele já estivesse o germe "da individualidade que devia atingir em [Memórias póstumas de] Brás Cubas, em Quincas Borba, nos Papéis avulsos e em Várias histórias o máximo de virtuosidade". Segundo o crítico, a partir da história narrada pelo defunto autor Brás Cubas, na obra do artista fluminense, o romanesco cederia espaço à ficcionalização de tendências críticas, como se o Machado filósofo e pessimista se impusesse.

Todavia, as críticas publicadas na primeira recepção de Papéis avulsos já traziam este e muitos dos lugares-comuns interpretativos que seriam desenvolvidos e reforçados pela crítica machadiana do século XX. A resenha da Gazeta de Notícias publicada por autor anônimo, em 27 de outubro de 1882, aparece como a primeira, em perspectiva cronológica, a tratar das diferenças entre as fases da obra de Machado:

O tom dominante no volume que temos à vista é o que se pode chamar a segunda maneira do poeta, que, principalmente no romance e nos contos, tanto distingue-se da primeira. Agora, o enredo e mesmo o estudo dos personagens ocupam o segundo plano. $O$ que atrai especialmente a atenção do autor não é o conjunto: é a forma, o detalhe,

\footnotetext{
${ }^{6}$ Os dois primeiros elogios foram publicados pelo jornal $O$ Fluminense na edição de 3 de novembro de 1882 (SOB O TÍTULO, 1882, p. 2); os dois seguintes aparecem em uma espécie de anúncio de lançamento da obra na Gazeta da Tarde, alguns dias antes, em 26 de outubro (PAPÉIS AVULSOS, 1882b, p. 1); o penúltimo foi escrito por Gama Roza na crítica de 2 de novembro, também para a Gazeta da Tarde (ROZA, 1882, p. 1); o último está presente em crítica estampada em A Estação, em 15 de novembro do referido ano (BIBLIOGRAFIA, 1882, p. 242).
} 
o acessório, estas minima de que não curava o pretor antigo, nem cura muito o leitor comum. (PAPÉIS AVULSOS, 1882c, p. 1).

Tal resenha, além de destacar a importância que o escritor passava a atribuir à forma dos textos, bem como a pormenores que levariam a uma outra configuração e percepção dos enredos (com o geral e o anedótico cedendo espaço ao particular), tece comentários a respeito de uma espécie de "filosofia triste" que perpassa o livro como um todo. "A impressão geral é de aborrecimento e tédio", diz o texto, centrando-se particularmente nos escritos "Teoria do medalhão" e "O segredo do bonzo". Paralelamente, o autor anônimo debruça-se sobre os processos estilísticos levados a cabo por Machado, com destaque para o domínio manifesto por este de uma forma plástica e sutil, empregada com vistas a traduzir "todas as cambiantes do pensamento e todas as cabriolas da fantasia" (PAPÉIS AVULSOS, 1882c, p. 1). Cada conto e a ideia geral que esse encerra, assim, seriam o resultado de um processo minuciosamente conduzido pelo autor, em que avultariam como temas os antagonismos entre objetivo e subjetivo, realidade e aparência.

Por fim, além de fazer uma clara distinção entre uma primeira e uma segunda fases da literatura machadiana, sugere a Machado uma "terceira maneira", "mais alegre, mais sociável e mais social". Essa proposta também merece atenção, já que mais da metade dos contos publicados em Papéis avulsos havia saído antes na Gazeta de Notícias, e Machado continuaria publicando seus contos - e também diversas de suas colunas de crônicas em tal periódico, sem grandes rupturas em seu estilo literário que indiquem novas e profundas alterações. Mais especificamente, ao se referir de modo irônico ao caráter inócuo das campanhas contra medalhões e pomadistas passíveis de serem depreendidas de Papéis avulsos, o articulista parece vislumbrar a emergência de novo Machado, em que o tom moralista então adotado pelo escritor cederia espaço ao predomínio do humor, ou melhor, de uma espécie de "filosofia alegre".

Em sua crítica para a Gazeta da Tarde - talvez a mais longa dentre o conjunto publicado pelos jornais da época, ocupando todo o espaço do folhetim -, Gama Roza ${ }^{7}$ inicia o texto com o comentário de que Papéis avulsos teria o status de continuação da maneira que surgiu a partir de Memórias póstumas. Assim como na crítica publicada pelo referido autor anônimo na Gazeta de Notícias, o jornalista comenta que é difícil reconhecer "o poeta lírico e o escritor romântico de outrora" (ROZA, 1882, p. 1) nos dois

\footnotetext{
${ }^{7}$ Possível assinatura de Francisco Luiz da Gama Roza, jornalista formado em medicina que foi presidente das províncias de Santa Catarina e da Paraíba.
} 
livros dessa segunda maneira, mais enigmáticos, mais pessimistas e marcados por um "humor doentio". Ele resume tal transformação operada na prosa do autor como se ele tivesse trocado a "varinha mágica do charmeur, pelo látego e férula do moralista", isto é, sua pena deixava de produzir encantamento para infligir castigos, tendo em vista a proposta de denunciar os vícios da sociedade na qual se encontrava.

Gama Roza associa tal transformação ao embate de um Machado já desiludido com as condições desfavoráveis que o meio social brasileiro impunha às "produções mentais". "Nem glória, nem dinheiro, nem consideração. $O$ povo não sabe ler. Os analfabetos são numerosos como as areias do mar" (ROZA, 1882, p. 1). Nesse panorama em que "o mais cintilante volume de poesias" nada valeria se comparado ao "ar solene e correto dos medalhões", o autor das Memórias póstumas tisnaria com o pó cinzento do humor todas as "frontes torpes". Segundo Gama Roza, tomando como base o livro José de Alencar: perfil literário, de Araripe Júnior, haveria semelhanças entre tal estágio último da trajetória de Machado $^{8}$ e aquele já vivenciado pelo autor de $O$ guarani. Este, ao engajar-se nas questões do seu tempo, em detrimento de suas produções artísticas, experimentara apenas desgostos, o que lhe gerou "uma mágoa incurável, acompanhada de um pesadume horrível": "O céu dourado de sua pátria deixou-se aos poucos escurecer, e o entusiasmo dos primeiros anos transformou-se na raiva e no pessimismo" (ARARIPE JÚNIOR, 1882b, p. 138).

Além da elaboração desse paralelo, Gama Roza também teve a primazia de associar as novas orientações e ênfases da obra de Machado pósMemórias póstumas e a célebre crítica do autor carioca a $O$ primo Basílio, de Eça de Queirós, publicada em duas partes, alguns anos antes (1878), no folhetim do periódico $O$ Cruzeiro. Em tal texto avaliativo, o bruxo do Cosme Velho condenava o chamado "realismo", tão aclamado e reproduzido pelos novos literatos da época (ASSIS, 2008). Mais especificamente, ao tratar da constituição do romance queirosiano, Machado desaprova o que acredita ser a má construção dos personagens, destacando que, em regra, elas não apresentariam motivações psicológicas para suas ações. Para Gama Roza, o diagnóstico de tais deficiências no realismo de Eça de Queirós teria permitido a Machado de Assis construir a sua própria maneira, adaptando a perspectiva realista então vulgarizada ao seu modo de escrita. Assim, Papéis avulsos procuraria conciliar muita observação com muita análise psicológica

\footnotetext{
${ }^{8}$ Gama Roza não vislumbra uma terceira maneira de Machado. A fase pós-Memórias póstumas seria o "último estádio de um brilhante e completo desenvolvimento", um ponto final na trajetória do escritor em termos de estilo (ROZA, 1882, p. 1).
} 
e "um profundo conhecimento do homem individual e coletivo". Em vista disso, Gama Roza afirma que a coletânea poderia muito bem ser obra realista, não fosse a "ironia pungente" e o "humorismo contínuo" nela predominantes. Para o referido crítico, é como se o texto sobre Eça tivesse rendido frutos para o próprio Machado que, a partir dos pontos negativos que elencou no realismo do colega lusitano (antimodelo), foi capaz de criar a sua própria maneira, adaptando o realismo ao seu modo de escrita. ${ }^{9}$

Voltando à alegada passagem do escritor de uma primeira a uma segunda maneira, tem-se ainda um resenhista anônimo de $A$ Estação que adota um viés de caráter mais abertamente biográfico para explicar tal mudança de orientação literária na prosa machadiana a partir das Memórias póstumas de Brás Cubas. Para tanto, associa a "grande e fecunda" renovação que se operou no espírito do autor das Crisálidas às desilusões vividas por tal artista com o passar dos anos. Machado, graças ao dissabor da experiência acumulada, "produto natural e espontâneo da idade", não se deixaria mais levar pelo "entusiasmo irrefletido dos primeiros anos", tornando-se um artista "poderoso e sóbrio, perscrutador, original, moderno" (BIBLIOGRAFIA, 1882, p. 242). Lúcia Miguel Pereira viria a construir ponto de vista um tanto quanto similar em livro consagrado ao romancista em 1936: "Não guardando mais sobre a humanidade a menor ilusão, desvalido de qualquer crença, ele como que se despiu de tudo, para ser apenas um cérebro em atividade, um observador gratuito, um raciocínio implacável" (PEREIRA, 1936, p. 185). Por mais que o resenhista de A Estação, diferentemente de Lúcia Miguel Pereira, não mencione o episódio do longo retiro a que Machado teve de se submeter em decorrência de uma doença, fica evidente a correlação que o crítico também estabelece entre idade, experiência, observação e pessimismo no desabrochar de Papéis avulsos.

Tendo em vista tais propostas de secção e enquadramento da obra do escritor, a recepção a Papéis avulsos ressoa, de certa maneira, mais familiarizada com a aparente "nova maneira" do artista quando comparada com a parcela da crítica que teve de se defrontar, um ano antes, com as Memórias póstumas de Brás Cubas. Diante da anterior estranheza, a coletânea de contos aqui investigada, funcionando como uma espécie de confirmação daquilo que é visto como um novo caminho na escrita

\footnotetext{
${ }^{9}$ Sobre a peculiaridade do realismo antirrealista de Machado, Roberto Schwarz destaca: "[...] se nos ativermos aos modelos estabelecidos, parecerá mais razoável chamar Machado de antirrealista. Entretanto, se pensarmos no espírito peculiar do realismo, na sua ênfase na análise da sociedade contemporânea em movimento, podemos, de fato, considerá-lo um grande realista". Tendo isso em vista conclui que, "para efeitos de precisão e complexidade, digamos então que ele é um realista que trabalha ostensivamente com procedimentos antirrealistas" (SCHWARZ, 2010, p. 234-235).
} 
machadiana, parece sugerir aos resenhistas uma paisagem menos incomum, em cuja topografia eles já conseguem se mover com certa desenvoltura.

\section{Humorismo triste e singularidade}

É bem conhecida a asserção proferida por José Veríssimo em 1892, quando do lançamento de Quincas Borba, de que Machado de Assis não caberia nas classificações convencionais em "ismo" e "ista" então disponíveis. A única que lhe conviria, efetivamente, seria a de "humorista" (VERÍSSIMO, 1892 , p. 1). Todavia, antes de o crítico paraense aprofundar tal enquadramento que tem em vista ressaltar a singularidade machadiana no panorama das letras nacionais, a primeira recepção de Memórias póstumas de Brás Cubas já atentava para o caráter "espirituoso" do romance. Urbano Duarte (1881, p. 2), em meio às duras críticas que faz ao livro, não deixa de assinalar que a contestável filosofia que o autor destilava nas páginas do romance era temperada por um "humorismo de bom gosto", que fazia rir para não fazer chorar. Na revista $A$ Estação, Artur Barreiros, sob o pseudônimo Abdiel, referia-se ao romance, ainda em 1880 quando seus capítulos eram impressos pela Revista Brasileira, como uma "narrativa humorística" inspirada diretamente nos "humoristas ingleses", que não teria correspondente nas literaturas de ambos os países de língua portuguesa. Com a publicação do romance em suporte livresco, o crítico insiste em tal afirmação, bem como elenca uma série de adjetivos que dão conta da filosofia ora triste, ora cômica da obra: "É soberano, límpido, musical, colorido, grave, terno, brincalhão, conceituoso, magistral" (ABDIEL, 1881, p. 40).

Na recepção de Papéis avulsos, como desdobramento imediato de tais juízos em torno de Memórias póstumas de Brás Cubas, a indicação da presença do humorismo na obra do escritor começa a ganhar mais corpo e a se estabelecer, mais propriamente, como lugar-comum crítico. Todavia, nesse momento, ela vem atrelada a outro conjunto de atributos também costumeiramente aposto a Machado: ceticismo (doutrina filosófica) e descrença na humanidade. Para dar conta da relação entre esses qualificativos, alguns críticos de então se valem, sobretudo, das categorias paradoxais "humorismo triste" ou "pessimismo bem-humorado", as quais procuram englobar a mistura entre sério e cômico, elo fundamental nos pastiches realizados por Machado em cada um dos contos que compõem a coletânea ora examinada. 
Ao anunciar que o livro seria lançado ao fim do ano, a Gazeta de Notícias publica, em 11 de abril, uma nota afirmando que o volume em questão agruparia "contos mimosos e páginas humorísticas". Entretanto, na primeira crítica completa de Papéis avulsos, também publicada em tal periódico, em 27 de outubro do referido ano, o enfoque passa ao aspecto filosófico e triste da obra, quase como uma forma de crítica negativa (PAPÉIS AVULSOS, 1882c, p. 1). Dois dias depois, ao comentar o sucesso do livro, a mesma folha parece chegar a um "meio-termo", realizando um elogio horaciano a Papéis avulsos: "É um grande bem para o espírito o divertir-se; muito maior é instruir-se. A leitura que reúne em si as duas condições, assemelha-se a um fruto ao mesmo tempo delicioso e nutritivo" (O QUE DIZER, 1882, p. 1).

Não seria apenas a Gazeta de Notícias que trabalharia com tal contraponto entre o humorismo e a dimensão filosófica (pessimista) presentes na obra de Machado, oposição que estaria na base do caráter jocosério de sua prosa pós-Memórias póstumas de Brás Cubas. ${ }^{10}$ Além de estabelecer um paralelo direto entre a "filosofia triste" de Machado e o pensamento de Schopenhauer, Gama Roza, nas páginas da Gazeta da Tarde, argumenta no sentido de destacar que o humor e o sarcasmo presentes no texto machadiano teriam por objetivo, ao mesmo tempo, confirmar e temperar uma espécie de "descrença" que brotaria das páginas de Papéis avulsos:

Na opinião do ilustre pensador, sociedade é o que há de mais infame; toda essa gente está contaminada pelo vício e pelo crime; precisamos bem de uma pequena chuva de fogo purificadora da iniquidade; mas, enquanto ela não vem, tisnemos com o pó cinzento do humour, e marquem com o eletroliso ${ }^{11}$ do sarcasmo essas frontes torpes. (ROZA, 1882, p. 1)

Entre outros aspectos, Gama Roza toma o humor como as cinzas na testa do penitente no início da Quaresma, a sinalizarem-lhe os pecados e a necessidade de conversão. Por outro lado, sem se ater às finalidades, mas tendo em vista as motivações do humorismo de Machado, Carlos de Laet,

\footnotetext{
${ }^{10}$ Não por acaso Julio Dast, em crônica recolhida em anexo, refere-se a Machado como "o poeta das Americanas, o romancista de Helena, o filósofo das Memórias póstumas de Brás Cubas" (DAST, 1882, p. 2).

${ }^{11}$ Tal palavra significaria o mesmo que eletrólise, isto é, decomposição de um composto em seus componentes mediante a passagem de uma corrente elétrica. Optou-se aqui por manter a escolha lexical de Machado. Ver, a seguir, a nota 31, associada à resenha de Gama Roza transcrita na íntegra.
} 
responsável por cunhar a expressão "humorismo triste", não atribui ao autor de Papéis avulsos, diferentemente de Roza, o papel de moralista. Segundo ele, a melancolia que prevalece na ironia e na graça machadianas decorre do descompasso entre ficção e vida: a impossibilidade de o escritor viver nos mundos fabricados por sua pena faz com que ele, desiludido, tenha de descer das alturas e enfrentar as "patifarias circunstantes", sendo afligido pelos "pontudos cotovelos da realidade" (LAET, 1882, p. 1). Já o resenhista de $A$ Estação vale-se do rótulo "pessimismo bem-humorado" como meio de ressaltar que a ênfase no tratamento de aspectos negativos da existência empreendida pelo artista apresenta um caráter gracioso e belo, não se restringindo simplesmente a maldizer a natureza e o homem (BIBLIOGRAFIA, 1882, p. 242).

Quer no caso de ressaltar os fins, quer as origens, quer as particularidades do humorismo em Machado, os críticos não tratam de tal componente cômico de modo isolado: ele, em regra, aparece conjugado com o pessimismo e a filosofia também atribuídos à obra do escritor. Não por acaso, em 1897, Sílvio Romero (1897, p. 341) lhe repudiará "a mania filosofária, as patacoadas humorísticas e pessimisticantes". Segundo ele, "tirem estas vestes de faquir dos ombros do autor de Brás Cubas e ele mostrará o trajo de toda a gente" (ROMERO, 1897, p. 342). Se o crítico virulento pede que seu adversário seja despido especificamente de tais atributos, é porque esse trinômio ornava bem a singularidade de Machado, vestimentas estas que começaram a ganhar corpo na fortuna crítica de Papéis avulsos.

\section{Papéis avulsos no centro - a recepção da contística de Machado}

Se se mostra importante examinar a recepção de Papéis avulsos à luz dos lugares-comuns que foram sendo construídos em torno da produção, sobretudo romanesca, de Machado, vale também considerar na análise da referida obra, como parâmetro comparativo, a própria fortuna crítica contemporânea ao lançamento dos demais livros de contos do escritor. Seus textos curtos, publicados desde o início de sua trajetória literária, na década de 1870, até quase a data de sua morte, em setembro de 1908, foram avaliados e reavaliados a partir de diferentes perspectivas. Nesse processo, de modo análogo ao que se observa com os romances, Papéis avulsos ocupa posição central no que diz respeito a certas mudanças apontadas da crítica. Partindo 
de tal hipótese, convém avaliar como as percepções em relação ao autor como contista se davam antes e depois da coletânea em questão.

Seu primeiro e segundo livros de contos, respectivamente Contos fluminenses (1870) e Histórias da meia-noite (1873), ganharam acolhida diminuta $^{12}$ e pouco entusiasmada na imprensa. Em linhas gerais, os textos das obras foram considerados "contos e narrativas singelas" (CONTOS FLUMINENSES, 1870, p. 1), "alegres, espirituosos e morais" (SERRA apud MACHADO, 2003, p. 94), de "tom comedido e brando", uma "literatura amena" (FERREIRA, 1873, p. 1), de caráter "gracioso e elegante" (CONTOS FLUMINENSES, 1870, p. 1), com "perfume tão delicado, incapaz de ferir os ouvidos mais castos ou o pudor mais exigente" (SERRA apud MACHADO, 2003, p. 94). Ao mesmo tempo, alguns textos chegam a descrever a imaginação do escritor como, predominantemente, "escassa". Todavia, para Carlos Ferreira, por exemplo, essa observação se mostra elogiosa, na medida em que tal rótulo fazia com que Machado se distanciasse de escolas cujos livros provocam "escândalo do coração e grande estremecimento do sistema nervoso" (FERREIRA, 1873, p. 1). O mesmo resenhista, porém, parece reconhecer em "Ernesto de tal" e "Aurora sem dia"13 alguns dos traços que seriam reforçados pelos críticos que trataram da obra de "segunda maneira" do escritor, observando: "que excelentes ironias e que diabólicas sátiras" (FERREIRA, 1873, p. 1).

Quando da publicação de Histórias sem data (1884), livro imediatamente posterior a Papéis avulsos, um anúncio no Jornal do Commercio (SAHIO À LUZ, 1884, p. 3) refere-se à coletânea por meio de termos como "espírito filosófico", "humorismo", "cor local", "nossos costumes" e "tipos descritos com suma propriedade e graça". O anúncio em si já incorpora alguns dos termos que seriam utilizados pela crítica, tanto na contemporaneidade do autor como posteriormente. Algum tempo depois, na Gazeta de Notícias, Valentim Magalhães (1884, p. 1) publica crítica que focaliza principalmente os aspectos ditos universais da obra de Machado, descrito por ele como um filósofo triste e travoso vestido de poeta. Ao considerar os textos do contista como "modernos hoje, como ontem, como amanhã", posiciona o Machado pós-Memórias póstumas como um escritor que já se estabelecera ao lado de Schopenhauer, Stendhal e Sterne, entre outros gigantes. ${ }^{14}$ Ainda no mesmo mês, o jornal $A$ Estação publica uma

\footnotetext{
${ }^{12}$ Há um texto crítico de jornal sobre Contos fluminenses e outros três sobre Histórias da meia-noite.

${ }^{13}$ Ambos contos publicados em Histórias da meia-noite.

${ }^{14}$ Nesta crônica, Valentim Magalhães parece estabelecer um diálogo responsivo com crítica publicada quando do lançamento de Papéis avulsos a qual sugeria a Machado uma terceira maneira mais alegre.
} 
resenha na forma de carta, escrita por Alzira C. a Alice de Sá, em que aquela elogia o modo como Machado retrata a vida local ao mesmo tempo em que aborda o caráter global da obra dele, sem deixar de criticar o elemento amargo dos textos recentes e a representação feminina em Machado (C., 1884, p. 78). De modo geral, a recepção crítica de Histórias sem data nos jornais, embora muito elogiosa, revela-se também bastante escassa.

Em comparação com seu predecessor, Várias histórias (1895) tem uma acolhida razoavelmente vasta, mais próxima do fenômeno que ocorrera com Papéis avulsos. ${ }^{15}$ Resenhistas como Olavo Bilac e Valentim Magalhães, por exemplo, incluem a obra junto aos livros publicados a partir de Memórias póstumas, diferenciando uma primeira de uma segunda fase machadianas. Para o poeta parnasiano, de modo mais específico, Várias histórias tem "aquele mesmo amor da psicologia e aquela fina ironia que fazem Machado de Assis ser, sobre um artista, um pensador para quem a alma humana não tem segredos" (BILAC, 1895, p. 3). No Jornal do Commercio, um texto sem assinatura comenta como Machado não teria cedido à literatura mercantil "para as descrições e os quadros chamados realistas e a que a curiosidade de novas sensações atrai os leitores" (LIVROS E AUTORES, 1895, p. 1), ou seja, seu projeto literário não se alinharia ao realismo e ao naturalismo por convicções, como sugere Gama Roza ao comentar Papéis avulsos.

Páginas recolhidas (1899) e Relíquias de casa velha (1906) configuram-se como dois casos de publicações que contam com mais de um gênero, englobando, além dos contos, teatro e crônica no primeiro caso, e teatro e poesia no segundo. A recepção de tais obras, embora escassa, traz alguns detalhes interessantes. Leopoldo de Freitas (1900, p. 1), comentando Páginas recolhidas, destaca a sátira em Machado, que "não tem aspereza nem se torna sarcasticamente irritante". Já sobre Relíquias, Nunes Vidal (apud MACHADO, 2003, p. 282) acredita que o livro ostenta um "tom [...] e reflete sempre uma leve ironia, ora no fundo amarga, cruel, ora inofensiva, continuando a ser ironia apenas por uma questão de hábito, de feitio".

Para ele, a obra de Machado, tanto nos contos quanto no romance, parece de certa forma ter envelhecido e criado uma casca - há, na resenha, uma comparação do livro com Esaú e Jacó, a partir da qual o crítico afirma que Machado não seguiria mais escrevendo no registro do humour.

Segundo Magalhães (1884, p. 1), não conviria a ele, diante da filosofia pessimista e da poesia triste de seu colega de seção, solicitar a este último que se tornasse mais alegre: "Meta-me alvoradas e passarinhos nessa poesia, injete-me otimismo, contentamento, gargalhadas nessa filosofia. [...] Além de ultrapassar a sua missão, o crítico que tal fizesse, podia correr o risco de ferir a justiça, de falhar o alvo a que apontasse".

${ }^{15}$ Várias histórias contou com seis resenhas críticas. Cf. Machado (2003, p. 181). 


\section{À guisa de uma conclusão}

Como se pode perceber, Papéis avulsos apresenta-se como ponto central para se compreender o processo de consagração de Machado depois do lançamento das Memórias póstumas. De modo mais específico, a recepção de tal coletânea de contos, quando se têm em vista as leituras anteriormente empreendidas do referido romance, revela certa familiarização da crítica com a dita "segunda maneira" iniciada pelo satírico defunto autor Brás Cubas. Além disso, torna mais patentes as articulações do binômio humorismo e pessimismo filosófico na obra machadiana que, a partir de então, passa a ser concebida e resenhada. Ao mesmo tempo, em chave mais restrita, a repercussão de Papéis avulsos se destaca em termos qualitativos e quantitativos no conjunto da contística do autor, delimitando as balizas com que seriam recebidas as seletas de textos curtos por ele publicadas posteriormente.

Mas não ficamos por aí. A repentina liberação de energia ocorrida em Papéis avulsos (GLEDSON, 2006a, p. 70) e a sua posterior apreensão pela crítica repercutiriam não apenas sobre tal porção da obra que ainda seria produzida por Machado, mas também sobre a releitura de sua primeira coletânea de contos. Se, no ano de sua primeira edição, Contos fluminenses era visto como um livro ameno, singelo e de pouca imaginação, quando da segunda edição da obra em 1899, Medeiros e Albuquerque, sob o pseudônimo J. dos Santos, já vislumbrava nela traços que foram apontados pelos críticos com mais clareza a partir de Papéis avulsos. ${ }^{16}$ Assinala o resenhista:

Certo, o estilo dos Contos fluminenses não tem a maestria do das memórias de Brás Cubas ou do Quincas Borba. Mas o que havia de ser plena e radiante eflorescência, alguns anos mais tarde, já aí se revelava de modo seguro [...] a cada passo, junto de cada frase suspeita há o imediato corretivo de um gracejo, contra o romantismo dela. (SANTOS apud MACHADO, 2003, p. 215-216)

\footnotetext{
${ }^{16}$ Essa perspectiva analítica em torno de Contos fluminenses, que detecta na coletânea certo caráter embrionário do Machado pós-Memórias póstumas de Brás Cubas, pode ser encontrada mais recentemente em trabalho de Marta de Senna. Para ela, a coletânea já permite vislumbrar as feições daquele que viria a ser "o maior de nossos prosadores", capaz de elevar "nossa literatura ao patamar da melhor literatura ocidental" (SENNA, 2006, p. XXXV-XXXVI).
} 
Assim como José Veríssimo que, ao comentar a segunda edição de Iaiá Garcia, acredita que nessa obra já germinavam alguns dos elementos típicos dos livros de Machado escritos a partir da década de 1880, Medeiros e Albuquerque vislumbra em Contos fluminenses, anterior em oito anos ao referido romance, algo muito parecido. Embora com Memórias póstumas de Brás Cubas e Papéis avulsos se comece a falar muito em "segunda maneira" e em um escritor então transformado em filósofo, afirma-se também uma linha crítica que enxerga essas alterações de estilo como algo paulatino, cujos "germes" já estavam presentes desde o início da vida literária de Machado.

\section{Anexo: Proposta de edição da primeira recepção de Papéis avulsos ${ }^{17}$}

\section{Nota Editorial}

A presente proposta de edição procurou coligir todo o conjunto de notas informativas, críticas e resenhas a respeito do livro Papéis avulsos estampadas na imprensa da corte ao longo de 1882, ano em que a coletânea de contos em questão foi publicada pela editora Lombaerts \& C. Para chegar a tal material, de início, tomou-se como base levantamentos bibliográficos realizados por J. Galante de Sousa, Raimundo Magalhães Júnior e Ubiratan Machado. Em seguida, procedeu-se à pesquisa em coleções de periódicos oitocentistas disponíveis tanto em suporte impresso como em meio eletrônico, com destaque para a hemeroteca da Biblioteca Nacional e para a Biblioteca Brasiliana Guita e José Mindlin.

Tendo em vista o propósito de documentar a primeira recepção de Papéis avulsos, os escritos aqui reunidos, independentemente do gênero no qual se enquadram, foram dispostos em ordem cronológica, com seus respectivos títulos a encabeçar cada entrada.

Quanto à identificação de cada escrito, em alguns casos, fez-se necessário tomar como título as primeiras palavras que iniciam notas de curta extensão que se localizavam em meio às notícias então veiculadas. Em outros casos, o nome da seção nas quais certas críticas e resenhas mais extensas se encontravam serviu de base para a individuação. Com relação a esses últimos textos, muitas vezes, as informações sobre Papéis avulsos neles contidas faziam parte de folhetins mais longos que tratavam de assuntos

\footnotetext{
${ }^{17} \mathrm{O}$ material que deu origem a este anexo foi coletado com o auxílio de bolsa da Fapesp durante o desenvolvimento da pesquisa de Iniciação Científica intitulada "Machado de Assis em jornal e em livro: os diferentes suportes e os diferentes sentidos do conto 'Na arca'" (2016).
} 
diversos. Em tais ocorrências, o trecho aqui transcrito, seja por uma questão de pertinência e de falta de espaço, restringe-se basicamente à análise do livro, com um pequeno resumo, em nota de rodapé, sobre os assuntos anteriores ou posteriores.

$\mathrm{Na}$ medida em que os textos apresentados nesta proposta editorial foram escritos de acordo com a incerta e então vigente "ortografia usual", obedecendo, assim, a padrões variados, optou-se por lhes atualizar a grafia em conformidade com o Acordo Ortográfico da Língua Portuguesa de 1990. Tal medida, por sua vez, ainda tem por mérito facilitar o acesso ao conjunto. A pontuação de cada autor foi respeitada, apesar de terem sido realizadas pequenas intervenções, sobretudo, no uso de vírgulas, sempre com o objetivo de esclarecer passagens consideradas confusas ou de difícil compreensão.

Realizaram-se também a solução ocasional de erros tipográficos mediante a supressão ou o acréscimo de letras e a padronização de formatações especiais (negrito, itálico e sublinhado), bem como do uso das aspas. Ao mesmo tempo, procedeu-se ainda à padronização do uso de caixaalta e baixa, sublinha e itálico (com destaque para a atualização de alguns termos e remoção do grifo de outros que, no século XIX, apresentavam-se como palavras estrangeiras) de modo a conferir unidade ao todo.

Notas de rodapé foram utilizadas com o fito de apresentar informações bibliográficas mais específicas de cada escrito, fornecer dados mínimos a respeito de seus autores (nos casos das composições assinadas), bem como elucidar pontualmente referências, retomando, quando possível, os diálogos do tempo da primeira veiculação dos textos aqui coligidos.

Por fim, com relação à crítica em francês publicada pelo Messager du Brésil e transcrita pelo Jornal do Commercio, optou-se por manter o texto na língua em que fora inicialmente publicado, já que a folha brasileira não apresentou uma tradução deste. Ainda quanto a ele, além da atualização ortográfica em conformidade com As Retificações Ortográficas do Francês de 1990, foram corrigidos tão somente alguns erros de grafia mais evidentes na transcrição apresentada pelo Jornal do Commercio. 
Este ano vamos ter um movimento literário como talvez ainda não tenhamos tido.

Machado de Assis publicará com o título de Papéis avulsos uma série de contos mimosos e páginas humorísticas.

Sílvio Romero publicará a primeira parte da Introdução à história da literatura brasileira, que vem das origens à malfadada escola de Minas [...]. ${ }^{18}$

\section{PAPÉIS AVULSOS...}

(Gazeta de Notícias, Rio de Janeiro, 26 out. 1882, p. 2)

Papéis avulsos é o título de um novo livro de Machado de Assis e que acaba de ser editado pelo sr. Garnier.

Limitamo-nos a agradecer o exemplar que recebemos, enquanto não apreciamos o livro, como merecem os elevados méritos do ilustre literato que o firma.

\section{$* * *$ \\ PAPÉIS AVULSOS...}

(Gazeta da Tarde, Rio de Janeiro, 26 out. 1882, p. 1)

É o título do novo volume de contos que acaba de publicar o estimável romancista Machado de Assis.

Este livro nos merece especial menção e será, em nossa folha, objeto de apreciação e do comentário a que tem direito um dos homens, que mais heroicamente hão concorrido para romper o indiferentismo que cerca as nossas letras.

\section{$* * *$ \\ PAPÉIS AVULSOS}

\footnotetext{
${ }^{18} \mathrm{O}$ texto segue com a exposição de uma série de informes sobre outras obras que seriam lançadas naquele ano, com destaque para o trabalho de outro grande crítico da obra de Machado, Araripe Júnior (1882b), com seu José de Alencar: perfil literário.
} 
Machado de Assis acaba de brindar as letras pátrias com mais um de seus encantadores volumes.

Papéis avulsos chama-se este, que contém fantasias e contos, dados à luz em diferentes publicações entre as quais a Gazeta de Notícias. ${ }^{19}$

O tom dominante no volume que temos à vista é o que se pode chamar a segunda maneira do poeta, que, principalmente no romance e nos contos, tanto distingue-se da primeira.

Agora, o enredo e mesmo o estudo dos personagens ocupam o segundo plano. O que atrai especialmente a atenção do autor não é o conjunto: é a forma, o detalhe, o acessório, estas minima de que não curava o pretor antigo, nem cura muito o leitor comum.

Qualquer dos seus contos apresenta uma ideia, uma observação desfiada, desenvolvida, propinada a pequenos goles: mas a ideia quase sempre não passa de pretexto, - e o produto é apenas o meio de empregar os processos.

Qual o sentido do volume de Machado de Assis não é difícil descobrir, depois de lê-lo com atenção: é todo insistir no antagonismo entre o objetivo e o subjetivo, entre a realidade e a aparência.

Dado um fato qualquer, o autor mostra primeiro os fatores que parecem tê-lo motivado, e depois investiga os que realmente o motivaram.

Para chegar a tal resultado são necessárias muita perspicácia, muita observação e mesmo certa inexorabilidade. O autor possui certas qualidades, a que dá novo realce o domínio que exerce sobre a forma, uma forma plástica e sutil, que traduz todas as cambiantes do pensamento e todas as cabriolas da fantasia.

É uma filosofia triste, devemos declará-lo. Apesar de nem todos os doze papéis inspirarem-se nela, a impressão geral é de aborrecimento e tédio, pois que julgamo-nos e julgamos os outros piores do que antes. Também com La Rochefoucauld ${ }^{20}$ sucede o mesmo; porém, por nessa parte, preferimos para estrangular-nos a corda rija e áspera do moralista francês à branca liga de seda com que nos acata a musa do poeta fluminense.

\footnotetext{
${ }^{19}$ Dos doze contos que compõem Papéis avulsos, sete foram publicados na Gazeta de Notícias: "Teoria do medalhão" saiu impresso na folha em 1881, enquanto "O segredo do bonzo", "O anel de Polícrates", "O empréstimo", "A sereníssima República", "O espelho" e "Verba testamentária" ganharam as páginas do periódico ao longo de 1882.

20 François de La Rochefoucauld (1613-1680), moralista francês a cuja tradição Machado é recorrentemente associado. Destacou-se com a publicação das Máximas (1665), consideradas pessimistas e desabusadas, e uma das leituras preferidas do romancista brasileiro.
} 
Sem dúvida é muito útil desfibrar medalhões e dar a receita da pomada, ${ }^{21}$ principalmente numa sociedade como a nossa, em que medalhões e pomadistas pululam, bracejam e dominam; mas a utilidade desta campanha é menor do que parece.

Suponhamos que com a "Teoria do medalhão" Machado de Assis conseguisse desmoralizar a raça. Quem seria então presidente do conselho? Quem deliberaria no conselho de estado? Quem presidiria o Instituto Histórico? Quem comporia a direção dos bancos e das secretarias?

E o que seria o Brasil sem estes aparelhos essenciais?

Quanto à pomada, o nosso distinto colega não nos parece que tenha maior razão.

A pomada é o laço que prende o solitário às multidões: é o que por conseguinte estende e reforça a influência dos fortes; é um mediador plástico, o primeiro móbil, o fiat etc. Sem a pomada, onde estaria o mundo?

Machado de Assis acabará reconhecendo-o, estamos certos, e brevemente nos dará outros trabalhos em que o tom seja mais alegre, mais sociável e mais social.

Será a sua terceira maneira.

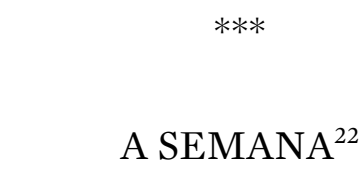

(Gazeta da Tarde, Rio de Janeiro, 28 out. 1882, p. 1)

Araripe Júnior ${ }^{23}$

[...] Três vezes venturosos são aqueles que, longe do bulício da política, mergulhados na vida ideal do gabinete, conseguem sanear o próprio espírito com a contemplação da natureza e da humanidade em abstrato.

\footnotetext{
${ }^{21}$ Referência ao bonzo de nome "Pomada" e a suas doutrinas, presentes no conto "O segredo do bonzo", o sexto da coletânea Papéis avulsos.

${ }^{22}$ A crítica divide espaço com comentários de Araripe sobre outros acontecimentos da semana em questão. Além da resenha de Papéis avulsos, o crítico comenta a exposição de diferentes tipos de cafés então realizada na Tipografia Nacional, iniciada ao final do ano anterior, para prosseguir com uma reflexão sobre a civilização e sobre a sessão legislativa daquele dia.

${ }^{23}$ Considerado um dos principais críticos brasileiros do século XIX, Araripe Júnior (1848-1911) destaca-se, até hoje, como um dos três pilares que têm norteado os estudos machadianos (GUIMARÃES, 2004b).
} 
Tem carradas de razão o estimado poeta Machado de Assis em ocupa[r] os seus lazeres com a composição de seus belos livros.

É muito melhor, muito mais fortificante preocupar-se a gente com o que devia ser o Brasil do que com o que ele é na realidade.

De quanta utilidade não seria pensarmos, refletirmos nas verdades que se encerram naquela notável teoria sobre o medalhão, em que o filósofo poeta estampa um dos mais característicos fatores da nossa decadência?

Acaso não está na consciência de todos que a nossa máquina governamental move-se por um impulso há longos anos adquirido?

Que os homens que entram na composição dos gabinetes são peças que substituem outras já gastas, e que quando penetram na engrenagem não aparecem como um elemento novo, como um aumento de força própria ao maquinismo, se não como o tipo convencional e indispensável à manutenção do ritmo costumeiro?

Somos com efeito um país de medalhões; e o autor dos Papéis avulsos faz ressaltar o caráter atrofiante com que essa espécie funesta desenvolve-se, difunde-se em todas as relações da vida pública no Brasil.

Os medalhões são as moléculas de que se compõe todo este grande corpo que afronta o Atlântico, prolongando-se desde a foz do Amazonas até as repúblicas do Prata.

Suprime-as, e já não teremos o país singular que conhecemos, em que vegetamos, em que nos contorcemos por falta de espaço para movermo-nos.

Mas o que vale para os que vivem engolfados na louca ambição do dia, para os que vivem mergulhados na miragem do poder, a palavra, embora conceituosa, de um poeta?

Os vícios que nos corroem entranham-se no sangue.

Há revoluções que se operam com dificuldades enormíssimas.

A expurgação do vírus é neste caso quase uma rejuvenescência, uma reconstituição.

Essa reconstituição depende do movimento do caráter, da energia, de todos aqueles elementos enfim que são indispensáveis ao fato da autonomia nacional.

\section{$* * *$ \\ O QUE DIZER...}

(Gazeta de Notícias, Rio de Janeiro, 29 out. 1882, p. 1) 
O que dizer do sucesso literário da semana - dos Papéis avulsos?

É um grande bem para o espírito o divertir-se; muito maior é instruirse. A leitura que reúne em si as duas condições, assemelha-se a um fruto ao mesmo tempo delicioso e nutritivo.

É de Marmontel ${ }^{24}$ este conceito, aplicável ao livro que vai ser procurado pelos que desejam distrair-se, admirando-lhe o fundo profundamente filosófico, e pelos que podem instruir-se, estudando-lhe a forma severamente castigada.

\section{$* * *$ \\ MICROCOSMO: CRÔNICA SEMANAL ${ }^{25}$}

(Jornal do Commercio, Rio de Janeiro, 29 out. 1882, p. 1)

Carlos de Laet $^{26}$

Abram vossas excelências e senhorias lugar na sua biblioteca para mais um bom e espirituoso livro do sr. Machado de Assis: - Papéis avulsos reunião de contos e artigos humorísticos, alguns dos quais já foram devidamente apreciados, quando figuraram no rodapé das folhas diárias favorecidas pela colaboração do distinto escritor.

Não destoa o livro dos que o precederam, firmados pelo mesmo nome: afinou-se mais o estilo e guardou-se felizmente a graça e originalidade das outras imaginações do autor.

Lembra ele, em advertência preliminar, palavras de S. João e Diderot para escusar a leveza de tais composições. Não era preciso tanto. Bastava mandar virar a página. Da primeira à última do livro corre o sopro da inspiração, mas trazendo, como o da brisa, por sobre as asas perfumosas, miríades de germens a esvoaçarem procurando o solo onde frutifiquem.

\footnotetext{
${ }^{24}$ Referência ao historiador e escritor francês Jean-François Marmontel (1723-1799), membro do movimento dos Enciclopedistas.

${ }^{25}$ A crítica divide espaço com outros comentários de Laet referentes, por exemplo, aos quadros expostos na Academia de Belas-Artes, ao teatro no Brasil, e ao parlamento. O trecho do texto de Carlos de Laet que trata sobre Machado foi integralmente reproduzido em "Autores e livros" (1941), e no terceiro volume do livro Vida e obra de Machado de Assis (MAGALHÃES JÚNIOR, 1981, p. 33-34).

${ }^{26}$ Carlos de Laet (1847-1927) foi um jornalista, poeta e professor carioca, membro fundador da Academia Brasileira de Letras (cadeira n. 32). Em 1878, foi substituído por Machado de Assis na assinatura da coluna "Notas Semanais", folhetim hebdomadário publicado aos domingos no jornal $O$ Cruzeiro.
} 
Pelos novos contos de Machado de Assis passará a imensidade de leitores; mas bem poucos serão os que sob a lápide conceituosa do licenciado Pedro Garcias saberão desentranhar o tesouro de que reza a historieta prólogo do Gil Braz. ${ }^{27}$ Nem outra é a feição característica dos contos, que devem oferecer distração apenas aos que com ela se contentam, e ensinamento também aos que procuram até nas horas de lícitas diversões.

Tem-se notado que das últimas produções do sr. Machado de Assis ressumbra certo humorismo, talvez por demais carregado de tristeza. A dosagem do humorismo, segundo os formulários em voga, é de partes iguais de melancolia e jovialidade. Mas os poetas, como Heine e Machado de Assis, sempre deitam mais absinto...

A razão é fácil de explicar. Naturezas mais impressionáveis, também mais devem eles sofrer com o aspecto das deformidades que a todo instante lhes apresenta a observação cotidiana. Enquanto poetas, vivendo de ambrosia e de rimas, têm ampla licença para fabricar mundos a seu jeito... Quando dessas esferas baixam ao planeta que habitamos, a desilusão é grande... Começam a viver em prosa e sentem por todos os lados a magoarem-nos incivilmente os pontudos cotovelos da realidade... Então falam, escrevem, riem como os outros, mas em suas expressões divisa-se o amargo desdém que lhes merecem as patifarias circunstantes, e nos seus mesmos sorrisos há um quê de saudade pelos outros mundos, os tais que eles fabricaram, mas não podem gravitar no verdadeiro, no real sistema planetário, sujeito a tantas perturbações e cometices.

Tenho de mim para mim que o humorismo triste do sr. Machado de Assis nasceu no primeiro dia em que com o pé da botina deu em alguma das patotas que de vez em quando assaltam a secretaria da agricultura... Quem vê desses monstros, vive triste com certeza.

Querem vê-lo contente, risonho, satisfeito? Não o demitam, não, porque sem ser ele um dos nossos melhores e mais laboriosos escritores, morreria de fome, se o obrigassem a viver só de suas letras: mas deem-lhe uma licença como as de que gozam outros funcionários, isto é, por toda a vida e com vencimentos por inteiro, sob a condição de produzir uns tantos volumes por ano.

\footnotetext{
${ }^{27}$ Referência à obra História de Gil Braz de Santilhana, escrita por Alain-René Lesage (1668-1747). Trata-se de uma novela de estilo picaresco, em que um jovem inicia estudos na Universidade de Salamanca, mas é coagido a ajudar um grupo de salteadores. Ao final da obra, ocupa a condição de amigo do rei e goza de sua fortuna em um castelo. No episódio de Pedro Garcias, dois estudantes se deparam com uma lápide que traz a inscrição "aqui está encerrada a alma do licenciado Pedro Garcias", sob a qual está enterrado o dinheiro de Pedro Garcias, conforme descobre o estudante mais velho ao desvendar o enigma da inscrição.
} 
Romances, em lugar de relatórios, e em vez de fastidiosos ofícios, papéis avulsos, como os que acabam de ser publicados!

\section{OS PAPÉIS AVULSOS, POR MACHADO DE ASSIS ${ }^{28}$}

(Gazeta da Tarde, Rio de Janeiro, 2 nov. 1882, p. 1)

Gama Roza ${ }^{29}$

Os Papéis avulsos são, na essência e na modalidade, uma continuação da maneira iniciada nas Memórias de Brás Cubas. ${ }^{30}$

O mesmo maneirismo, o mesmo pessimismo, o mesmo ar sarcástico, cético, desiludido de tudo e de todos, as mesmas revelações apocalípticas, os mesmos sentidos obscuros e ambíguos, o mesmo humorismo doentio, o mesmo espírito enigmático, fazem desconhecer, no primeiro como no segundo livro, o poeta lírico e o escritor romântico de outrora.

O fato possui significação e merece ser aprendido: trata-se não de uma mudança momentânea, um movimento acidental, mas de uma impressão perduradoura, de um novo modo de ser adquirido pela individualidade do escritor.

O elegante poeta fluminense irrevogavelmente trocou assim a varinha mágica de charmeur, pelo látego e a férula do moralista.

E moralista de mais feroz catadura, severo e puritano.

Na opinião do ilustre pensador, sociedade é o que há de mais infame; toda essa gente está contaminada pelo vício e pelo crime; precisamos bem de uma pequena chuva de fogo purificadora da iniquidade; mas, enquanto ela não vem, tisnemos com o pó cinzento do humor, e marquem com o eletroliso $^{31}$ do sarcasmo essas frontes torpes. Por toda a parte pululam os medalhões, os pomadistas, os parasitas, os boêmios, os caloteiros, os trampolineiros de eleições, os cacetes autores de dramas, os ambiciosos sórdidos, os invejosos miseráveis. Vícios, infâmia, loucura são coisas que não existem individualmente porque são o apanágio da multidão; a probidade, a

\footnotetext{
${ }^{28}$ A resenha ocupa toda a seção do folhetim do jornal.

${ }^{29}$ Possível assinatura de Francisco Luiz da Gama Roza (1814-1892), um jornalista formado em medicina que foi presidente das províncias de Santa Catarina e da Paraíba.

${ }^{30}$ A palavra "póstumas" no título da obra não consta do texto saído no jornal.

${ }^{31}$ No original, "electrolyso". Ubiratan Machado optou por transcrever esse termo como "eletrólise" (MACHADO, 2003, p. 141).
} 
honra, a virtude, tudo isso foge covardemente apenas surge um interesse importante...

Filosofia triste, triste e verdadeira! Pura filosofia de Schopenhauer, ${ }^{32}$ o Diógenes ${ }^{33}$ alemão.

Araripe Júnior, no seu estudo sobre José de Alencar, ${ }^{34}$ acentuou de modo bem notável a radical transformação operada no espírito e na maneira do nosso primeiro romancista. ${ }^{35}$

Agora surge o mesmo fenômeno em Machado de Assis.

O fato, de especial que era, generaliza-se e convém, sobre ele, deter a atenção.

Nenhum meio social é, mais do que o nosso, desfavorável às produções mentais. A inconsciência pública suprime todas as aspirações. A trampolina eleitoral, o ar solene e correto de medalhão, alguns empenhos têm mais valor aos olhos de todos que o mais cintilante volume de poesias, ou a mais profunda monografia científica. Nem glória, nem dinheiro, nem consideração. O povo não sabe ler. Os analfabetos são numerosos como as areias do mar. De vez em quando surge pela barra o indispensável reforço: novas levas de portugueses, pela maior parte rotineiros, inimigos irreconciliáveis das letras e do progresso.

Nessas tristes condições, sob a ação desse meio desfavorável, ou o espírito, quando fraco, sucumbe, que é o que sucede no maior número dos casos, ou se é forte e poderoso, irrita-se, luta contra a opressão, adquire as ferocidades do animal acuado.

No caso vertente, convém ainda enumerar outras coisas. A vida é um fato muito complexo para ser encerrado numa fórmula.

Machado de Assis, mais do que José de Alencar, teve ocasião de ser espectador interessado, e quiçá hostil, da violenta e total mutação realizada no mundo das ideias.

\footnotetext{
${ }^{32}$ Arthur Schopenhauer (1788-1860) foi um filósofo alemão amplamente conhecido por uma filosofia do pessimismo. Schopenhauer é frequentemente citado por Machado ao longo de sua obra. Uma de suas principais referências aparece na famosa crônica "O autor de si mesmo", veiculada no jornal $A$ Semana em 1865, em que comenta a obra Metafísica do amor a partir de uma notícia publicada em um periódico gaúcho pouco tempo antes.

${ }^{33}$ Diógenes de Sinope (404/12 a.C.-323 a.C.) foi um filósofo da Grécia Antiga conhecido também como Diógenes, o Cínico. Em seu ideal de autossuficiência, Diógenes pregava uma vida que fosse natural e não dependesse das luxúrias da civilização.

${ }^{34}$ Gama Roza refere-se à obra José de Alencar: perfil literário de autoria de Araripe Júnior (1882b) publicada naquele mesmo ano pela Typ. da Escola de Serafim José Alves, Editor.

35 "O céu dourado de sua pátria deixou-se aos poucos escurecer, e o entusiasmo dos primeiros anos transformou-se na raiva e no pessimismo" (ARARIPE JÚNIOR, 1882b, p. 138).
} 
Todos sofreram mais ou menos a culbute geral; mas, Machado de Assis, escritor já constituído, certamente experimentou um repercutimento mais intenso.

Desilusões, esperanças mortas, o esboroamento do velho mundo romântico, a brutalidade das transições bruscas, a insolência invasora das ideias novas teriam determinado, como em José de Alencar, o acúmulo e o transbordamento daquelas ondas negras e amargas como as do lago Asfaltite? ${ }^{36}$

Estarão destinados, todos os nossos poetas líricos, todos os nossos antigos tenores, ardentes e apaixonados, a trocar o manto de seda e o chapéu de pluma pela toga austera e o barrete sombrio do velho doutor Fausto? ${ }^{37}$

São interrogações. Mas há muito rancor e muito ódio naqueles Papéis avulsos para que a personalidade do autor se ache desinteressada.

Não se distingue ali do escritor naturalista que refere todas as grandezas e todas as ignomínias, com calma exatidão, com imparcialidade, friamente, como quem redige uma observação científica.

Por toda a parte transparece o antigo romântico apaixonando-se pela narração, intervindo na luta, vindicando agravos, rancoroso e implacável.

Se não fora esse fato, se não fora a intensão, ostensivamente manifestada da ironia pungente, no humorismo contínuo, nas reflexões venenosas, teríamos nos Papéis avulsos um belíssimo trabalho realista, porquanto exista ali muita observação, muita análise psicológica, um profundo conhecimento do homem individual e coletivo.

Mesmo o estilo do eminente escritor modificou-se sob a influência dos novos processos, e se não há perfeita adaptação, existe pelo menos uma aproximação notável.

O estilo sintético, o período curto, rápido, conceituoso, a colocação das palavras e a pontuação, mesmo alguns tics da escola nova, tudo se acha ali fundido com a maneira exata, correta, peculiar ao autor.

Vê-se bem que não foi em vão aquele estudo e aquela notável crítica sobre Eça de Queirós. ${ }^{38}$

As boas ideias, mesmo quando combatidas, fascinam e fazem conversões.

\footnotetext{
${ }^{36}$ Outro nome para o Mar Morto.

${ }^{37}$ Referência ao protagonista da lenda alemã que deu origem ao poema trágico homônimo de Goethe. Na lenda, Fausto faz um pacto com o demônio.

${ }^{38}$ Trata-se de uma referência às críticas ao romance $O$ primo Basílio publicadas por Machado em 1878 no jornal $O$ Cruzeiro em 16 e 30 de abril.
} 
O único meio de arredar ideias, o autor sabe, é usar permanentemente daquele regime quarentenário, preconizado na "Teoria do medalhão".

Faremos agora ao distinto escritor um reproche minúsculo, mas que agastou-nos os nervos.

Aquele reproche do prólogo faz logo em começo uma péssima impressão, agravada ainda pela nota do fim do volume. ${ }^{39}$

Pois o eminente escritor dá realmente importância a essa minuciosidade preciosa?

Quem atualmente se lembra de prestar atenção a questões de galicismos, anglicismos, germanismos, turquismos ou outras frivolidades do mesmo jaez?

Quatro caturras decrépitos.

Desde que sejam necessárias, boas, expressivas, venham as palavras donde vierem, serão sempre aceitas com especial agrado.

Compreende-se que José de Alencar fizesse aquelas cerebrinas contendas de palavras, procurando justificar-se; as noções científicas sobre o transformismo em linguística não se sonhavam ainda entre nós convenientemente vulgarizadas, e o grande romancista vivia cercado de cães de fila puristas. Essa raça, porém, desapareceu ou tornou-se inofensiva. ${ }^{40}$

Portanto, use do reproche...

O notável estilista inclui no seu trabalho dois brilhantes pastiches: "O segredo do bonzo" e "Na arca".

Os cultores da forma, os artistas da plástica, os escritores para os quais as modalidades sutis do pensamento não oferecem dificuldades, desejam o esforço, procuram embaraços e deslizam, como Balzac e Gonçalves Dias, para o pastiche.

As deslocações, os saltos mortais para trás, os voos sérios, representam em ginástica o mesmo papel que o pastiche representa no clownismo literário.

Resumindo: o trabalho de Machado de Assis é a todos os respeitos muito notável; aquelas páginas dos Papéis avulsos não são escritas, são cinzeladas; quer pelas ideias, quer pelo estilo, a obra possui a força das coisas perduradouras, sendo em tudo digna do escritor eminente de reputação

\footnotetext{
${ }^{39} \mathrm{O}$ resenhista refere-se à Nota $\mathrm{A}$, presente no conjunto de notas que Machado apõe ao final da edição princeps de Papéis avulsos. Nela, o contista discute a etimologia da palavra "reproche" a partir do recebimento de duas cartas anônimas que condenam o uso de tal galicismo. O trecho na íntegra pode ser lido na página 293 da primeira edição da coletânea (ASSIS, 1882).

40 Provável referência ao "Pós-escrito" à segunda edição de Iracema, publicada em 1870 pela editora Garnier. Nesse paratexto, Alencar faz, sobretudo, considerações acerca de regras ortográficas e defende-se da pecha de "escritor incorreto e descuidado".
} 
legitimamente estabelecida, chegando ao último estádio de um brilhante e completo desenvolvimento.

\section{SOB O TÍTULO PAPÉIS AVULSOS}

(O Fluminense, 3 nov. 1882, p. 2)

Sob o título Papéis avulsos acaba de publicar o distinto literato sr. Machado de Assis uma coleção de doze contos e fantasias. Seria o caso de empregar-se a bem conhecida chapa - basta o nome do autor para recomendar a obra, porque nenhum dos nossos literatos tem hoje reputação mais firmada do que aquele sr.

Preferimos porém tratar do livro, deixando em paz o nome do autor.

O estilo destes escritos é primoroso, notando-se-lhe sobretudo a pureza e a graça. Quase todos eles tendem a demonstrar o antagonismo existente entre a aparência e a realidade, antagonismo que é incontestável, mas que as conveniências sociais procuram algumas vezes envolver no silêncio.

Merecem especial menção nesse livro os trabalhos intitulados - "O alienista", "Teoria do medalhão" e "O segredo do bonzo".

O primeiro, notável pelo seu humorismo, é a história de Simão Bacamarte, que no intuito de estudar a patologia cerebral, funda em Itaguaí um hospital de loucos, aonde recolhe primeiro todos os que tinham as faculdades mentais desequilibradas e depois todos os que as pareciam ter equilibradas, acabando por se recolher unicamente a si próprio, por julgar pelo consenso geral ter em si os característicos do perfeito equilíbrio mental e moral. Há nesse conto um estudo de caracteres, triste talvez, porém verdadeiro, em que o autor parece ter tido em vista demonstrar o rifão: todo o homem tem sua veia de doido.

"Teoria do medalhão" encerra excelentes conselhos, filhos de uma fina observação, para se fazer figura na sociedade independente de qualquer mérito. No nosso país, onde as reputações surgem do dia para noite, sem base, e onde os sábios não precisam dar provas de si, esta parte do livro do sr. Assis é um tesouro de inapreciável valor.

"O segredo do bonzo" como descoberta não tem grande valia, porque já é muito conhecido na nossa terra. Não há ninguém que não esteja convencido que entre nós mais vale parecer do que ser em matéria de virtude e saber. Este escrito, pois, só como trabalho de crítica e de estilo pôde 
merecer aplausos, e os merece bem. Lá quando a vir divulgar as lições do bonzo Pomada, chegou tarde: há muito que conhecemos já todos os segredos do pomadismo.

As demais produções merecem ser lidas e julgamos prestar um serviço aos nossos leitores recomendando-lhes a leitura dos Papéis avulsos do sr. Machado de Assis.

\section{CHRONICAS FLUMINENSES ${ }^{41}$}

(Revista Illustrada, Rio de Janeiro, 4 nov. 1882, p. 2)

[...] Gostam de contos? A casa Garnier acaba de reunir e publicar os Papéis avulsos do sr. Machado de Assis, onde mais de uma joia literária se descobre.

O poeta das Americanas, o romancista de Helena, o filósofo das Memórias póstumas de Brás Cubas tem o seu lugar marcado na literatura brasileira, sobretudo como um progressista que é. É preciso tê-lo acompanhado como eu, desde os seus primeiros trabalhos, para apreciar o seu espírito sempre ativo e admirar o seu talento sempre progredindo, vencendo-se cada dia a si próprio, no estilo sobretudo! Eu sei que para muita gente o estilo e mesmo a gramática não têm grande valia; não há muito tempo escreviam-nos do outro lado do Atlântico:

"A gramática ainda não levou ninguém à posteridade" e desta banda todos aplaudiram, sem que ninguém se lembrasse de que:

- Nem a falta de gramática tampouco! Mas eu tenho talvez o mau gosto de preferir o bom vinho num copo de cristal de Boêmia a bebê-lo num vaso de barro dos indígenas.

Sem fazer crítica dos novos contos de Machado de Assis, eu prevenirei todavia a leitora que há em muitos deles mais do que uma história divertida e bem contada, há um ensinamento; o autor é um filósofo. Um filósofo que faz trocadilhos. Querem um? A sra. Ignez, uma atriz do nosso teatro que fala

\footnotetext{
${ }^{41}$ Trata-se da última seção em que se divide o texto do autor publicado sob a rubrica "Chronicas Fluminenses".

42 Segundo Magalhães Júnior, trata-se de pseudônimo utilizado pelo responsável pela seção "Chronicas Fluminenses" da Revista Illustrada (MAGALHÃES JÚNIOR, 1981, p. 109).
} 
como se diz pelos cabelos, saía uma manhã do banho escorrendo ainda água quando encontra o poeta.

- Oh!, ines...gotável, brada-lhe, o poeta.

PAPÉIS AVULSOS, por Machado de Assis $^{43}$

(Jornal do Commercio, Rio de Janeiro, 4 nov. 1882, p. 2)

Xavier de Carvalho ${ }^{44}$

Nous avions déjà lu et relu, avec un plaisir infini, ces contes humoristes, ces historiettes délicates qui, pour la plupart ont déjà été publiées dans les journaux quotidiens. Il semble que, réunies en volume, elles prennent une certaine unité et que la série d'études que l'auteur appelle si modestement Papéis avulsos mériterait plutôt d'avoir pour titre Un collier de perles.

Pour bien mettre en lumière tout ce qu'il y a d'humain et de délicat dans le nouveau livre de M. Machado de Assis, il faudrait pouvoir joindre l'exemple à l'assertion et citer au moins quelques passages où l'écrivain met en scène des types si vivants, qu'il serait aisé de mettre un nom connu sur la physionomie. Lisez "O alienista", "O empréstimo", "Verba testamentária" et vous serez surpris autant que charmé par l'exactitude dans les détails et la finesse dans l'observation. Il est impossible de se détacher de cette œuvre maîtresse lorsqu'on en a commencé la lecture. Quelle vie dans ces tableaux tour à tour mondains et populaires. Comme le mot arrive toujours à propos pour peindre l'objet ou la pensée; voilà du vrai réalisme, non le réalisme grossier qui affecte de n'être qu'une photographie brutale, mais la sincérité d'impression, la peinture d'après nature laissant constamment entrevoir derrière l'observateur, le philosophe.

Machado de Assis n'appartient à aucune école; si les tendances de son talent rappellent un peu le tempérament bizarre et étrange de Baudelaire, le traducteur de ce fou qui eut nom Edgar Poe, son style brillant et châtié à la fois, la ciselure aristocratique de la phrase, rappelle mieux encore la manière

\footnotetext{
${ }^{43}$ Reprodução de uma crítica em francês, estampada no jornal Le Messager du Brésil, em 29 de outubro de 1882. Uma versão traduzida do texto em questão encontra-se em Machado de Assis: roteiro da consagração, de Ubiratan Machado (2003), na qual se explicita a atribuição da autoria a Xavier de Carvalho.

${ }^{44}$ Xavier de Carvalho (1862-1919) foi um jornalista português e um dos correspondentes em Paris de $O$ Paiz e da Gazeta de Notícias.
} 
de Daudet. C'est surtout de lui qu'on pourrait dire ce que disait Ernest Daudet de son frère ainé: "Quelque effort qu'on fasse pour lui imposer une étiquette, cet effort restera vain. Il est lui-même, c'est là l'essence de son originalité native, la marque personnelle de son œuvre".

Pour terminer, félicitons l'éditeur, M. Garnier, auquel les lettres brésiliennes sont redevables de si nombreux et si signalés services, d'avoir compris que le nouveau volume de M. Machado de Assis méritait une exécution typographique soignée. Le livre imprimé chez MM. Lombaerts et C. ne laisse rien à désirer et est digne en tous points de la réputation qu'ils ont su acquérir depuis longtemps.

\section{BIBLIOGRAFIA $^{45}$}

(A Estação, Rio de Janeiro, 15 nov. 1882, p. 242)

Papéis avulsos, por Machado de Assis. - Para todos os que escrevem e para todos os que leem, é patente que uma grande e fecunda renovação se operou no espírito do autor das Crisálidas, e que o Machadinho de 1860 se transformou num escritor poderoso e sóbrio, perscrutador, original, moderno.

Data essa renovação das Memórias póstumas de Brás Cubas, livro tão escassamente entendido e em tanta maneira admirável, que já teria feito a volta do mundo, se não fosse escrito em português.

Os Papéis avulsos, dados agora a público, obedecem visivelmente à nova orientação literária do autor e continuam com o mesmo brilhantismo a sua segunda maneira, que me parece participar, em doses iguais, da fina ironia de Swift, ${ }^{46}$ do pessimismo de Schopenhauer, do realismo de Daudet e disto que anda no ar, que não se pode definir e a que chamarei de espírito do tempo.

Dois escritores, ${ }^{47}$ aliás distintos, não lhe toleram 0 pessimismo desalentador e doentio que se dilui como um veneno, corrosivo e impalpável,

\footnotetext{
${ }^{45}$ Na mesma página, na seção "A Cidade e os Theatros", assinada por J. Dantas, consta o seguinte parágrafo que faz menção à coletânea de contos: "A leitora já deve ter lido os Papéis avulsos do sr. Machado de Assis e, bastante maliciosa penetrou facilmente toda a filosofia, que em alguns dos contos o poeta encobre com a sua graça e primor de estilo."

${ }^{46}$ Referência a Jonathan Swift (1667-1745), autor inglês conhecido, entre outros aspectos, por seu estilo irônico e satírico.

${ }^{47}$ Um dos "dois escritores" mencionados seria, com certeza, Urbano Duarte, autor de dura resenha ao livro Memórias póstumas de Brás Cubas estampada na Gazetinha, em 2 de fevereiro de 1881. O segundo
} 
nas suas páginas recentes e descobrem nele o propósito de demonstrar que o egoísmo é o único fator das ações humanas.

Pessimismo, não dissimulo que há, mas um pessimismo que não é nem a rabuge caduca da velhice, nem a caturreira de um emperrado, que por toda a parte visse a ruína e a morte, que se sentisse invadido pela treva e o mal.

Um pessimismo bem-humorado, fino, risonho, e delicioso, que se não fecha à chave para poder maldizer da natureza e do homem, que não é insensível ao bom e ao belo; mas que se não deixa levar pelo entusiasmo irrefletido dos primeiros anos: produto natural e espontâneo da idade, da experiência, da observação, tal se nos afigura o pessimismo do Brás Cubas e dos Papéis avulsos.

Quanto ao egoísmo, não é impossível que um espírito obcecado e estéril o descubra no fundo das ações humanas e até na própria sentença, que é a base e o princípio da religião cristã: Não faças a outrem o que não queres que te façam.

Todavia, não me parece que um poeta, uma natureza excepcionalmente dotada, ponha empenho em lograr tão mesquinho escopo.

Como quer que seja, porém, se o escritor é substancialmente pessimista, - transitório ou definitivo, não importa - a forma é de um apuro deslumbrador, ateniense, irresistível, cheio de nugas como a ironia da mulher bonita.

O sr. Machado de Assis é dos que entendem, e ainda bem, que as ideias não bastam a formar o escritor, é preciso também fixá-las, por intermédio da arte, com um estilo próprio, copioso, imperecedouro; porque esta estreita união do engenho e da arte é a característica de todas as obras-primas. ${ }^{48}$

poderia ser João Ribeiro, que naquela oportunidade já se encontrava no Rio de Janeiro, embora tenha começado a conviver com Machado de Assis apenas a partir de 1885 (MACHADO, 2008, p. 297). Esse intelectual não poupou críticas ao "profundo escárnio pela sociedade" manifesto pelo egoísmo "sem limites" de Machado. Outra possibilidade seria Sílvio Romero que, no ano de 1882, publicou o livro $O$ naturalismo em literatura. Nesta obra, ele se refere a Machado como "um lamuriento, um burilador de frases banais, um homenzinho sem crenças... uma irrisão" e a Memórias póstumas de Brás Cubas como "bolorenta pamonha literária" (ROMERO, 1882, p. 37 e 40).

${ }^{48}$ A seção ainda tem continuidade com quatro pequenos parágrafos sobre a Conferência no Grêmio Literário Castro Alves realizada por Guilherme Bellegarde. 


\section{Referências}

1. Primeira recepção de Papéis avulsos

ARARIPE JÚNIOR. A Semana. Gazeta da Tarde, Rio de Janeiro, 28 out. 1882a, p. 1. BIBLIOGRAFIA. A Estação, Rio de Janeiro, 15 nov. 1882, p. 242.

DAST, Julio. Chronicas Fluminenses. Revista Ilustrada, Rio de Janeiro, 4 nov. 1882, p. 2.

ESTE ANO VAMOS [...]. Gazeta de Notícias, Rio de Janeiro, 11 abr. 1882, p. 1.

LAET, Carlos de. Microcosmos. Jornal do Commercio, Rio de Janeiro, 29 out. 1882, p. 1.

O QUE DIZER [...]. Gazeta de Notícias, Rio de Janeiro, 29 out. 1882, p. 1.

PAPÉIS AVULSOS [...]. Gazeta de Notícias, Rio de Janeiro, 26 out. 1882a, p. 2.

PAPÉIS AVULSOS. Gazeta da Tarde, Rio de Janeiro, 26 out. 1882b, p. 1.

PAPÉIS AVULSOS. Gazeta de Notícias, Rio de Janeiro, 27 out. 1882c, p. 1.

PAPÉIS AVULSOS por Machado de Assis. Jornal do Commercio, Rio de Janeiro, 4 nov. 1882 d, p. 2.

ROZA, Gama. Os Papéis avulsos por Machado de Assis. Gazeta da Tarde, Rio de Janeiro, 2 de nov. 1882, p. 1.

SOB O TÍTULO [...]. O Fluminense, Rio de Janeiro, 3 nov. 1882, p. 2.

2. Textos em geral

ABDIEL [pseudônimo de Artur Barreiros]. Bibliografia - Memórias póstumas de Brás Cubas, por Machado de Assis. A Estação, Rio de Janeiro, 28 fev. 1881, p. 40.

ABREU, Capistrano. Livros e letras. Gazeta de Notícias, Rio de Janeiro, 30 jan. 1881, p. 2.

ARARIPE JÚNIOR. José de Alencar: perfil literário. Rio de Janeiro: Typ. da Escola de Serafim José Alves, Editor, 1882b.

ASSIS, Machado de. Memórias póstumas de Brás Cubas. Rio de Janeiro: Typographia Nacional, 1881. . Papéis avulsos. Rio de Janeiro: Lombaerts \& C., 1882. . Literatura realista. In: Obra completa em quatro volumes. Organização de Aluizio Leite Neto, Ana Lima Cecilio e Heloisa Jahn. 2. ed. Rio de Janeiro: Nova Aguilar, 2008. v. 3, p. 1232-1242.

AUTORES E LIVROS. A Manhã, n. 7, 28 set. 1941, p. 22.

BILAC, Olavo. Livros novos. A Cigarra, Rio de Janeiro, n. 25, 24 out. 1895, p. 3.

C., Alzira. Histórias sem data. A Estação, Rio de Janeiro, 15 dez. 1884, p. 78.

CALDWELL, Helen. Machado de Assis: the Brazilian Master and His Novels. Berkeley, Los Angeles: University of California Press, 1970. 
CONTOS FLUMINENSES. Diário do Rio de Janeiro, Rio de Janeiro, 17 fev. 1870, p. 1.

DUARTE, Urbano. Bibliografia - Memórias póstumas de Brás Cubas. Gazetinha, Rio de Janeiro, 2 fev. 1881, p. 2.

FERREIRA, Carlos. Histórias da meia-noite. Correio Paulistano, São Paulo, 27 dez. 1873, p. 1.

FREITAS, Leopoldo de. Páginas recolhidas. O Paiz, Rio de Janeiro, 22 jan. 1900, p. 1.

GLEDSON, John. A história do Brasil em Papéis avulsos, de Machado de Assis. In: Por um novo Machado de Assis: ensaios. São Paulo: Companhia das Letras, 2006a, p. 70-90.

. O machete e o violoncelo: uma introdução aos contos de Machado de Assis. In: Por um novo Machado de Assis: ensaios. São Paulo: Companhia das Letras, 2006b, p. 35-69.

. Papéis avulsos: um livro brasileiro? In: ASSIS, Machado de. Papéis avulsos. Introdução de John Gledson e notas de Hélio de Seixas Guimarães. São Paulo: Companhia das Letras, 2011, p. 7-32.

GUIMARÃES, Hélio de Seixas. Os leitores de Machado de Assis. São Paulo: Edusp; Nankin, 2004a.

. Romero, Araripe, Veríssimo e a recepção crítica do romance machadiano. Estudos Avançados, São Paulo, vol. 18, n. 51, maio-ago. 2004b, p. 269-298.

. O impacto da obra de Machado de Assis sobre as concepções de romance. Machado de Assis em linha, ano 1, n. 1, jun. 2008, p. 29-39. Disponível em: <http://machadodeassis.net/download/numero01/num01artigo04.pdf $>$. Acesso em: 8 dez. 2018. . Machado de Assis, o escritor que nos lê. São Paulo: Editora Unesp, 2017.

HALLEWELL, Laurence. O livro no Brasil: sua história. 2. ed rev. e ampl. São Paulo: Edusp. 2005.

JÚNIO, D. [José Ribeiro Dantas?]. Bibliografia. Revista Illustrada, Rio de Janeiro, 15 jan. 1880, p. 6.

LIVROS E AUTORES - algumas publicações recentes. Jornal do Commercio, Rio de Janeiro, 30 out. 1895 , p. 1.

MACHADO, Ubiratan (Org.). Machado de Assis: roteiro da consagração (crítica em vida do autor). Rio de Janeiro: EdUERJ, 2003.

Dicionário de Machado de Assis. Rio de Janeiro: Academia Brasileira de Letras, 2008.

MAGALHÃES, Valentim. Notas à margem. Gazeta de Notícias, Rio de Janeiro, 20 nov. 1884 , p. 1.

MAGALHÃES JÚNIOR, Raimundo. Vida e obra de Machado de Assis. Rio de Janeiro: Civilização Brasileira; Brasília: INL, 1981. v. 3.

PEREIRA, Lúcia Miguel. Machado de Assis: estudo crítico e biográfico. São Paulo: Companhia Editora Nacional, 1936 (Brasiliana, vol. 73).

PLEBISCITO LITERÁRIO. A Semana, Rio de Janeiro, 13 ago. 1887, p. 4.

POMPEIA, Raul. Livro da porta. Revista Illustrada, Rio de Janeiro, 3 abr. 1880, p. 2. 
RECEBEMOS. Gazetinha, Rio de Janeiro, 12 jan. 1881, p. 1.

ROMERO, Sílvio. O naturalismo em literatura. São Paulo: Typographia da Provincia de São Paulo, 1882.

Machado de Assis: estudo comparativo de literatura brasileira. Rio de Janeiro: Laemmert \& C., 1897.

SAHIO À LUZ [...]. Jornal do Commercio, Rio de Janeiro, 16 ago. 1884, p. 3.

SCHWARZ, Roberto. Um avanço literário. Literatura e Sociedade, São Paulo, vol. 15, n. 13, p. 234-247, 2010.

SENNA, Marta de. Introdução. In: ASSIS, Machado de. Contos fluminenses. Edição preparada por Marta de Senna. São Paulo: Martins Fontes, 2006, p. IXXXXVI.

VERÍSSIMO, José. Um novo livro do sr. Machado de Assis. Jornal do Brazil, Rio de Janeiro, 11 nov. 1892, p. 1-2.

Bibliografia - Iaiá Garcia, por Machado de Assis. Revista Brasileira, Rio de Janeiro, 1898, p. 249-255.

THIAGO MIO SALLA é doutor em Ciências da Comunicação e em Letras pela Universidade de São Paulo. Enquanto docente e pesquisador da Escola de Comunicações e Artes da USP e do Programa de Pós-graduação em Estudos Comparados de Literaturas de Língua Portuguesa da FFLCH/USP, dedica-se às áreas de Literatura Brasileira, Teorias e Práticas da Leitura e Editoração. Entre outros trabalhos, publicou o livro Garranchos Textos inéditos de Graciliano Ramos (Record, 2012) e Graciliano Ramos e a cultura política (Edusp, 2017). (D) http://orcid.org/0000-0001-5009-5157. E-mail: thiagosalla@usp.br

LUIZA HELENA DAMIANI AGUILAR é mestranda e bolsista CNPq no Programa de PósGraduação em Estudos Comparados de Literaturas de Língua Portuguesa pela FFFLCH/USP. Possui bacharelado em Comunicação Social com Habilitação em Editoração pela Escola de Comunicações e Artes da mesma universidade (2016). Desenvolveu pesquisa de Iniciação Científica intitulada "Machado de Assis em jornal e em livro: os diferentes suportes e os diferentes sentidos do conto 'Na arca'" com bolsa da FAPESP. 